\title{
Modern Islam, Politics, and the Making of Religious Commodification Among Female Members of Majelis Taklim Circle in Bandar Lampung, Indonesia
}

\section{Mulyadi}

Universitas Islam Negeri Raden Intan Lampung mulyadi@radenintan.ac.id

\section{Tontowi Jauhari}

Universitas Islam Negeri Raden Intan Lampung tontowijauhari@radenintan.ac.id

\section{Mansur Hidayat}

Universitas Islam Negeri Raden Intan Lampung mansurhidayat@radenintan.ac.id

\section{Arif Sugiono}

Universitas Lampung

Arifsugiono01@gmail.com

Abstract : Despite the common belief in society about the declining fate of religion in time of modernity, everyday behaviors of religious societies have shown that religion has been increasingly commodified for political purposes. This article aims to study the ways in which modernity has enabled the dynamic use of religious commodification in political sectors. Its main question is how political leaders have used religious doctrines, values, and symbols for gaining their electoral supports. Data of this research is collected through surveys among female Muslim members of Islamic learning circles (majelis taklim) in Bandar Lampung, the biggest city in the province of Lampung, where religious learning circles have increasingly flourished in the last few years. This research finds out ample evidence showing the significant influences of modernization and commodification of religion in determining political behaviors of the female members of Islamic learning circles. 
Mulyadi, et.al.

Modernization in the context of this research is defined as knowledge, urbanization, increased income, technological progress, social norms, social interaction, social institutions, and commodification of religion is identified as the acts of making religious teachings and activities as a commodity, empirically manifested in the form of transforming social relations into economic relations (relation oriented for economic interests, materialization of a thing spiritual).

Keywords : Religious Commodification, Modernity, Female Muslim, Muslim Politics.

Abstrak : Terlepas dari kepercayaan umum di masyarakat tentang takdir kemerosotan agama di zaman modern, perilaku sehari-hari masyarakat beragama menunjukkan bahwa agama semakin dikomodifikasi untuk kepentingan politik. Artikel ini bertujuan untuk mempelajari bagaimana modernitas telah memungkinkan dinamika pemanfaatan komodifikasi agama di sektor politik. Pertanyaan utamanya adalah bagaimana para pemimpin politik menggunakan doktrin, nilai, dan simbol agama untuk mendapatkan dukungan elektoral mereka. Data penelitian ini dikumpulkan melalui survei pada perempuan Muslim anggota majelis taklim di Bandar Lampung, kota terbesar di provinsi Lampung, dimana lingkungan belajar agama semakin berkembang dalam beberapa tahun terakhir. Penelitian ini menemukan banyak bukti yang menunjukkan pengaruh signifikan modernisasi dan komodifikasi agama dalam menentukan perilaku politik perempuan anggota kelompok belajar Islam. Modernisasi dalam konteks penelitian ini diartikan sebagai pengetahuan, urbanisasi, peningkatan pendapatan, kemajuan teknologi, norma-norma sosial, interaksi sosial, pranata sosial, dan komodifikasi agama yang diidentifikasikan sebagai tindakan menjadikan ajaran dan kegiatan agama sebagai komoditas, yang terwujud secara empiris. dalam bentuk mentransformasikan relasi sosial menjadi relasi ekonomi (relasi yang berorientasi pada kepentingan ekonomi, perwujudan sesuatu yang spiritual).

Kata Kunci : Komodifikasi Agama; Modernitas; Perempuan Muslim; Politik Muslim.

\section{A. Introduction}

Western scholars tend to undermine the progressive nature of Islam as a religion, and its ability to inspire a spirit of liberation among Muslim societies. They are reluctant to acknowledge the roles of Islam in the development of human civilization, despite modern history has shown to us that Islam has played significant roles in the world's civilization, along with 
other political, economic, ethnic, social, and other factors. ${ }^{1}$ Eickelman and Piscatori, for example, have maintained that Muslims and Islam are compatible with modern democratic politics. ${ }^{2}$ There is no longer a need to reconcile between the religious and the politics in Islam, although there has been several attempts to combine Islamic faith with political movements (Islamism and militancy), making it plausible for non-Muslims to think that Islam is a religion of militancy. ${ }^{3}$

Issues about modern Islam, religion, and politics will continue to become heated debates in public spheres, where the advance of technology has rendered more visible the different views embraced among members of a secular, modern, rational, commercial, and material society. Views of such society in matters related to religious politics are also diverse. In a broader spectrum, the concept of secularization places religion as a commodity, considering religion as a marketable item. Commercialization of religion has resulted in a decline of religious belief in society, and a fading away of religious values which are considered divine and sacred. Berger explained that modernization always leads to the decline of religion, both in society and in individual thought. ${ }^{4}$

Giggie and Long have argued that the power of religion and market has rendered possible the commodification of a certain object. According to them, in many religious traditions, the religious and the commercial have never been an each other's foe; yet, on the contrary, both of them have always been mutually interrelated. ${ }^{5}$ The facts that religion has been a profitable commodity sold by many politicians during every electoral rally incite an important question about the ways in which modernity, politics and commodification of religion could influence political behaviors of religious individuals and groups in a given society.

\footnotetext{
${ }^{1}$ Johan Hendrik Meuleman, ed., Islam in the Era of Globalization (New York: Routledge, 2002), p. 151.

${ }^{2}$ Filippo Osella and Benjamin Soares, ed., Islam, Politics, Anthropology (United Kingdom: John Wiley \& Sons, Ltd, 2010), p. 5.

${ }^{3}$ Richard C. Martin dan Abbas Barzegar, ed., Islamism: Contested Perspectives on Political Islam (California: Stanford University Press, 2010), p. 34.

${ }^{4}$ Pattana Kitiarsa, Religious Commodifications in Asia (New York: Routledge, 2008), p. 3.

5 Vineeta Sinha, Religion and Commodification: Merchandizing Diasporic Hinduism (New York: Routledge, 2011), p. 190-91.
} 
Many researches on religious commodification have been done in various contexts. Fakhruroji and Ahimsa, observing the practice of texting religious messages via SMS services (SMS Tauhid), argued that such practice has been closely related to religious commercialization. ${ }^{6}$ Zaenurrosyid and Ulfiana claimed that there has been a practice of religious commodification among pilgrims and sellers around the tomb of the Sheikh Ahmad Mutamakkin, who based their transaction decisions upon moral and economic behavior. ${ }^{7}$

Suprapto and Miftahul Huda observed the practices of religious commodification around a Muslim residential development project in Lombok, and they found out that motivation of business and other mundane considerations appeared more prominent in that project, despite an image of Islamic ideals was still maintained among a few of the project's developers. ${ }^{8}$ Abdul Malik and Ariyandi Batubara argued that many politicians in Indonesia have (ab)used religious symbols in order to gain electoral power, by making a politician's face picture as a cover of a prayer book, such as 'Buku Yasin' (the Yasin book), or by collaborating with an ulama in order to increase the politician's electability. ${ }^{9}$ Asmaul Husna argued that the trend of Islamic consumption was pervasive and amusing because it looks religious. Yet, such trend was capitalized by many businessmen to reap off as much profit as possible, and in turn inviting not only a new understanding about Islam, but also an emerging lucrative market, the Muslim middle-class groups. ${ }^{10}$

William Robertson has used the term sacred to identify actions, beliefs, institutions, species, and traditions that are related to religion, and has pointed out the importance of distinguishing the sacred from the

\footnotetext{
${ }^{6}$ Moch. Fakhruroji, “Agama Dalam Pesan Pendek: Mediatisasi dan Komodifikasi Agama Dalam SMS Tauhiid” (Yogyakarta, Universitas Gadjah Mada, 2014), http://publikasi.pasca.ugm.ac.id/catalog/?v=publikasi\&id=365.

${ }^{7}$ A. Zaenurrosyid dan Lucy Zulies Ulfiana, "Komodifikasi Agama dalam Islamic Tourism dan Aktivitas Ekonomi," Islamic Review: Jurnal Riset dan Kajian Keislaman Vol 5, no. 1 (2018).

${ }^{8}$ Suprapto dan Miftahul Huda, Antara Penguatan Identitas danKomodifikasi Agama (Mataram: Universitas Islam Negeri Mataram, 2018).

${ }^{9}$ Ariyandi Batubara dan Abdul Malik, "Komodifikasi Agama dalam Ruang Politik di Seberang Kota Jambi," Kontekstualita: Jurnal Penelitian Sosial Keagamaan Vol. 29, no. 2 (2014).

10 Asmaul Husna, "Komodifikasi Agama: Pergeseran Praktik Bisnis dan Kemunculan Kelas Menengah Muslim,” Jurnal Komunikasi Global Vol. 2, no. 2 (2018).
} 
mundane when it comes to discussing religion. ${ }^{11}$ However, in realities, religion is often treated by politicians as a commodity that is sold during the elections - from local elections to the presidential election - in exchange of electoral supports. During the local elections, religion is often commodified to gain gain votes, especially within the basis of religious institutions and religion-based political parties. In Bandar Lampung, the situation is no exeption. As stated by Lili Bamban, "activities in a majelis taklim will usually become more intensified approaching the elections, be they the local election, the gubernatorial election, or the legislative election and the presidential election, as the campaign teams from participating parties and candidates will stay close to majelis taklim in Bandar Lampung". ${ }^{12}$

The utilization of majelis taklim sphere for political campaign - a form of a commodification of religion, is expected to influence the political choices of members of the majelis taklim. In order to understand how political contestants have accommodated religious values, symbols and figures for political commodities during the electoral contestations, commodification of religion is analyzed through the modernist behavioral approach, which is characterized by socio-demographic transformation, rational choice theory, and the changes of social structures. This research was conducted in various majelis taklim in Bandar Lampung, especially those located in the districts of Kemiling, Panjang, Way Halim, Sukabumi and Sukarame. These districts have the largest number of female voters, majority of who are not only Muslims, but also members of a majelis taklim. $^{13}$

Data related to the commodification of religion and the modernist views of the political contestants and members of the majelis taklim are collected to answer the paper's main question, that is, "what are the influences of religious commodification performed by political contestants who have made religious values, dogmas, and symbols as commodities to attain electoral votes, towards the political behavior of the female members of majelis ta'lim in Bandar Lampung?". This research pointed to the significant role of the modernist views of the political contestants in making religious symbols, values, and dogmas as political commodities, which in

${ }^{11}$ Gregory D. Alles, Religious Studies: A Global View (New York: Routledge, 2008), p. 18.

${ }^{12}$ Lili Bambang, interview with the writer in his home, on July $13^{\text {th }}, 2019$

13 "PORTAL Berita Resmi Pemerintahan Kota Bandar Lampung," diakses 30 Agustus 2019, https://bandarlampungkota.go.id/new/kecamatan.html. 
turn have influenced the political behavior of members of the majelis taklim congregations in Bandar Lampung.

This paper begins with an exploration about on how the entanglement between Islam, politics, modernity, and market has enabled the process of religious commodification in contemporary Muslim society. After that, it discuss about issues related to the commodification of religious thoughts within the scope of the majelis taklim in Bandar Lampung. Then this paper discusses about the correlation of modernity and the commodification of religion, the relation between majelis taklim and political contestants, to the formation of socio-political behavior of the majelis taklim members. It concludes this discussion by putting emphasis on the effect of modernity on the commodification of religion.

\section{B. Commodification and Modernity}

\section{Commodification of Religion}

Commodification is the process of transforming things into valuable products that can be exchanged for goods as a substitute. ${ }^{14}$ Pattana Kitiarsa defines commodification as an act of changing or treating something into a commodity, a commercialization of an activity, which basically is not commercial in nature. ${ }^{15}$ Commodification can also be seen as a main tool to transform social relations into economic ones. ${ }^{16}$ While commodification of Islam may refer to processes of commercializing Islam, or a process in which Islamic symbols are turned into something that is profitable. ${ }^{17}$ In order for an object to be turned into a commodity, that object must have the following characteristics: valuable and marketable. ${ }^{18}$

Furthermore, commodification can be defined as an attempt to turn an object or a service into something that has a commercial value. The occurrence of religious capitalism is largely generated by the tendency of capitalism to render any valuable thing into marketable products, either in

${ }^{14}$ Vincent Mosco, The Political Economy of Communication (London: SAGE Publication Ltd, 2009), p. 2.

${ }^{15}$ Kitiarsa, Religious Commodifications in Asia, p. 6.

${ }^{16}$ Muhammad Ferri Setiawan, "Commodification of Religious Tradition" (The 3rd Conference on Communication, Culture and Media Studies, Yogyakarta, 2016), p. 38.

${ }^{17}$ Abdur Rozaki, "Komodifikasi Islam: Kesalehan dan Pergulatan Identitas di Ruang Publik,” Jurnal Dakwah Vol. XIV, no. 2 (2013): 203.

${ }^{18}$ Ibid. 
the form of goods or service. Thus, to the extent that religion has been one the most valuable entities in human's history, it is prone to become an object of commodification in society. ${ }^{19}$ Commodification, however, is not a point that goes away from the subject into the object being commodified, but also from the object into a pure exchange. ${ }^{20}$ Thus, religious commodification can be interpreted as the process of altering religious values, dogmas, symbols, and artifacts into products that are traded (market value) in order to get a substitute for the commodified product (profit).

The power of religious symbols and artifacts lies in their ability to become a rich source of meaningful values. In the world of business and politics, they are prone to be turned into commercial goods, transforming the religion into economic products and pushing it into the so-called a religious market. As a symbolic economic activity, commodification of religion may develop very rapidly. Religious symbols are turned into something marketable, and they are sold in every moment that is spectacular, bringing them to various scales and modes of market transactions in modern and rational societies.

Contemporary capitalism has converted a non-economic environment such as religion into a market society, characterized by commercialism and consumerism. In the context of contemporary capitalism, all aspects of society become goods that can be commercialized for profits. ${ }^{21}$

Religious commodification is an intimate process, in which religious meanings and their sacredness become a commodity that is produced, exchanged, and consumed through market mechanisms. ${ }^{22}$ This process occurs because religious forces and markets are very close, especially seen from the cross-cultural and historical evidence of religious traditions,

\footnotetext{
${ }^{19}$ Husna, "Komodifikasi Agama: Pergeseran Praktik Bisnis dan Kemunculan Kelas Menengah Muslim,” p. 229-30.

${ }^{20}$ Sinha, Religion and Commodification: Merchandizing Diasporic Hinduism, p. 201.

${ }^{21}$ Okoli, "Materialism and Commodification of The Sacred: A Political Economy of Spiritual Materialism in Nigeria,” European Scientific Journal Vol. 10, no. 14 (2014): 595-96.

${ }^{22}$ Kitiarsa, Religious Commodifications in Asia, 7.
} 
proving that both the religious and the commercial have never been in opposing terms. They are, in fact, closely related to each other. ${ }^{23}$

There are three stages on how processes of commodification occur, according to the political economy research on communication. The first is commodification, that is, the process of changing valuable things into products that are sellable. The second is specialization. It is the process by which mass media and technology overcome the constraints of geographic space. The third is the creation of social relationships. ${ }^{24}$ The first process of religion commodification requires a means of communication and an access to the message of religious commodification.

The proliferation of religious commodity in public life such as Islamic pilgrimage to a tomb of Muslim saints and to Mecca (umrah), Muslim clothing, Islamic television programs et cetera, is a form of religious commodification that involves cultural products and services. ${ }^{25}$ According to political economists, to be a product of commodity, an object or a service needs to have the following aspects: content, audience, and labor. In this paper, religious commodification is seen from the side of the audiences and workers (politicians). The former is the members of majelis taklim congregation (the audience), who aspire to things labeled Islamic, such as Islamic tour to Mecca for doing umrah. The latter relates to the ability of workers (politicians) to sell religious symbols in a package that attracts the members of majelis taklim congregation, and that in turn shapes their political behavior.

\section{Modernism}

Modernity and tradition are two terms that have always been opposed to each other. Modernity is a process of moving towards into the present, or into a modern society. ${ }^{26}$ It can be interpreted as a transformation from a traditional society into the modern one. Modernization refers to something that is new, or to changes that happened in the world's social order. ${ }^{27}$ Shils defines modernity as a social leveling to reduce class

${ }^{23}$ Sinha, Religion and Commodification: Merchandizing Diasporic Hinduism, p. 190. 2014), p. 172.

${ }^{24}$ Ibid., p. 127-28.

${ }^{25}$ Mosco, The Political Economy of Communication, p. 141.

${ }^{26}$ Nanang Martono, Sosiologi Perubahan Sosial (Jakarta: Raja Grafindo Persada,

${ }^{27}$ Hidayat, Pemikiran Islam Kontemporer (Bandung: Pustaka Setia, 2005), p. 183. 
differences; state-guided industrialism; and development of rationalism, science, and expertise as a guidance for democratic institutions; and convergence in a consensual model of social organization based on progressive taxation and social benefit provision by the state. Modernization is understood as a process of transformation from a traditional society to a modern one..$^{28}$

The adjective word modern refers to something novel, the newest, or the latest one. While modernization may means a renewal or a tajdid, modernization in society's lives refers to thoughts, school of thoughts, movements, and efforts to negotiate and adjust old understandings, customs, institutions and so forth, according to the new circumstances brought about by the advance of science and technology. Modernization in Islamic terminology means a serious effort to reinterpret the understanding, thoughts, views about Islamic issues hold dear by the previous generation of Muslim thinkers, so as to make them compatible with the current conditions. ${ }^{29}$

Modernity may also refer to novel values that are resulted from cultural changes, largely generated by the advance of science and technology. Modernization itself is an effort to apply the modern values in every aspect of society's life. Islamic modernism can be said as a form of Muslim response to western modernity. ${ }^{30}$ It is a process of reinterpreting the understanding, thoughts, and opinions about Islamic values that come from previous generation of Muslim scholars, in order to make them adjustable to the changing times.

The construction of modernization lends credence to the classical thoughts, especially the theory of evolution, functional theory, and the theory of conflict. These theories are capable of explaining the processes of social transformation that took place in society. ${ }^{31}$ According to the theory of evolution, social transformation is a unidirectional, linear, progressive, and evaluative movement, which entails a society to transform towards an

${ }^{28}$ Hadiyanto, Komunikasi Pembangunan Perspektif Modernisasi (Bandung: IPB Press, 2014), p. 2.

${ }^{29}$ Abuddin Nata, Peta Keragaman Pemikiran Islam di Indonesia (Jakarta: Raja Grafindo Persada, 2001), p. 154-55.

${ }^{30}$ Bani Syarif Maula, "Islam dan Modernitas: Pandangan Muslim Terhadap Perkembangan Sosial," Fikrah: Jurnal Ilmu Aqidah dan Studi Keagamaan Vol. 5, no. 2 (2017): 356.

${ }^{31}$ Martono, Sosiologi Perubahan Sosial, p. 137. 
advanced stage, and encourages it to have its form and structure. Classical theories also stipulate the dualism of social forms; rational-irrational, mechanical solidarity, and organic solidarity, also in the form of developed countries and third world countries.

Based on the theory of evolution, modernization has several assumptions. First, modernization is considered a gradual process. Second, modernization is a homogenization process (forming similar characters and structures). Third, modernization usually means Europeanization, Americanization (westernization). Fourth, modernization is a process that does not move backward, meaning that the process of modernization cannot be stopped. Fifth, modernization is a progressive change (becoming something that is desired). Sixth, modernization requires extensive time. Seventh, modernization is a systemic process, in which change occurs in almost every aspects of life. Eighth, modernization is defined as a process of transformation for achieving modern statuses. Ninth, modernization involves a continuous process.

Lerner mentioned that modernization is related to a psychological process that allows a person to replace a traditional personality with a modern personality. This alteration takes place in a simultaneous way, transforming a traditional society into a modern one. The process of modernization (in the West) is expressed by Lerner as follows: "modernization consists of several components and sequences that have global relevance. Everywhere, a project of urbanization tends to focus on reducing illiteracy: for reduction in illiteracy will increase openness in society with regard to the consumption of mass media, thus generating the society's level of economic and political participation". 32

The key to this transformation process is personality, or more popularly known as empathy, defined here as the ability to put one's self in other people's conditions. Specific skills and knowledge are utterly needed among people who intend to break out from traditional circumstances. This conclusion is based on the fact that empathy is a salient personal ability found only in modern society. The ability to give empathy is needed in mental mobility, a sort of character transformation which must be multiplied expansively.

Modern society has certain features that are different from those of traditional societies. A traditional society is often referred to, for example,

\footnotetext{
${ }^{32}$ Hadiyanto, Komunikasi Pembangunan Perspektif Modernisasi, p. 3.
} 
rural peasants with their conservative attitudes, humble taste of life style, superstitious beliefs, fatalistic mentality, and dogmatic faith, characteristics that are seen by many as a major challenge and obstacle to the formation of a modern society. Another characteristic of traditional societies is their tendency to authoritarianism, low self-confidence, and resistance to ideas of reform and development. ${ }^{33}$

A modern society on the other hand, is characterized by its sociodemographic aspects and the structure of its social institutions. Sociodemographic aspects include socio economic elements and human psychology. Aspects of social demography are developed through new patterns of socialization and modern behavior such as urbanization, increasing income, and the use of technology. In the meantime, aspects of social structure take its place on society and social norms, which are shaped and reshaped through the social and cultural relations among members of the society. The modernity of social structures is related to social norms, social strata, social interaction, authority, and social institutions. ${ }^{34}$

Modernity in Islam emerged as a response to alleged backwardness of Muslim society especially in matters related to economy, education, science, culture, and politics. ${ }^{35}$ Such allegation is arguably at odds with the teachings of the Qur'an and Hadith, the two main sources of Islamic doctrines and knowledge, which advocate progressive thoughts and developmental ethics for the betterment of humankind. However, many Muslims fail to show attitudes and actions that are in accordance with the teachings of the Qur'an and Hadith, indicating their lack of understanding about Islam.

There are various factors that have caused the underdevelopment of Muslim societies. The first is Muslims' abandonment of fundamental teachings of Islam in favor of foreign thoughts. The second relates to political conflicts in Muslim societies, in which Muslim communities are highly polarized. The third is due to the decreasing feature of Muslim brotherhood around the world. The fourth is the lack of Muslim brotherhood. The fourth is the leniency of Muslims to a static attitude (jumud) with regard to practicing the religion. And the fifth is the

\footnotetext{
${ }^{33}$ Ibid., p. 27.

${ }^{34}$ Syamsul Bakri, "Modernisasi dan Perubahan Sosial Dalam Lintasan Sejarah Islam,” KALIMAHVol. 14, no. 2 (2016): 173, https://doi.org/10.21111/klm.v14i2.611.

${ }^{35}$ Nata, Peta Keragaman Pemikiran Islam di Indonesia, p. 158.
} 
production of bid'ah (invented Islamic practices not existent during the times of Muhammad) among Muslims, making them strayed from the true teachings of the religion. ${ }^{36}$

According to Bellah, the development of society in matters related to religion went through several stages: the primitive, the ancient, the historical, the early modern, and the modern. ${ }^{37}$ The first stage is characterized by the belief in myths and spiritual beings. The second stage, or the ancient period, is defined by the emergence of gods, padri-padri, worship, sacrifice, and the conception of the kingdom of God. The third stage, or the historical period, is characterized by the emergence of major world religions that existed a thousand years (millennia) before the Christ. The fourth stage is the early modern period which is marked by the emergence of Protestantism, which continued to bring forward the distinction of historical religions within the secular and other spheres. In last stage, or the modern period, religion is conceptualized as (part of) an everyday life, where traditional practices and rituals of religions diminish in public spaces, replaced by the rising concerns over humanistic ethics from the so-called secular threads.

It is this fifth stage of religious community that has become the focus of this research: that is, examining the religion that has lost its spiritual meanings. According to Bellah, modern religion is categorized into two theses. First, religion is questioned of its existence, and its significance in society is considered diminishing. Second, religion is understood as a residual element from socio-cultural systems.

Members of the majelis taklim congregation in Bandar Lampung, especially in the districts of Kemiling, Panjang, Way Halim, Sukabumi, and Sukarame, constitute as the largest female Muslim voters during the local and general elections. The members of the majelis taklim are active in carrying out religious activities, especially ahead of the general election. These activities were mostly attended by housewives. Through the majelis taklim activities, social relations and social structures are established, as many members of the majelis taklim were able to organize travelling to Mecca for umrah, meeting famous celebrity preachers, even the congregation has become a campaigning space for political leaders running in the local and general elections.

\footnotetext{
${ }^{36}$ Ibid., p. $158-60$.

${ }^{37}$ Martono, Sosiologi Perubahan Sosial, p. 321.
} 
Modern Islam, Politics, and the Making of Religious Commodification...

\section{The Impacts of Modernity on Religious Commodification}

Data on modernity and religious commodification were obtained by distributing questionnaires to 355 majelis taklim members in Bandar Lampung. The correlation test between modernity and religious commodification of the majelis taklim members of Bandar Lampung indicates that the correlation figure is 0.827 . This mean, it can be said that the two variables have a strong correlation.

The correlation between modernity and religious commodification is attained because modernization is understood as a means of reinterpreting the understanding, thoughts, and views about Islamic values, ethics, and issues. Modernity is also resulted from cultural transformation, influenced by the development of science and technology in all aspects of human's life. As such modernity is a response to the alleged underdeveloped conditions of Muslim societies, including in economics, education, science, culture, politics, and so forth.

On the other hand, changes in thoughts, culture, economy, education and politics will in turn enable the society to transform what they believed, thought, and practiced into a commodity. By turning what they believed into a commodity, what was in the past treated more as a cultural capital, is now reshaped into a means of economic transactions. This is also applied to all symbols and spaces considered as Islamic. In its extreme case, it may even converse faith into commercialization.

The correlation that modernization has had with the practices of religious commodification among members of the majelis taklim in Bandar Lampung can be seen from the background of its members. Most members of the majelis taklim are coming from urban areas and middle class backgrounds. The shift in economic orientation will give social benefit and economic profits members of the majelis taklim. Likewise, the increasing use of technology (smartphone) has enabled them to improve their relations with other members of the congregation, giving benefit to the maintenance of the shared norms, social class, and social interactions among the members. All of these factors have contributed to the complex interwoven between modernity and religious commodification.

After the data collected from the members of the majelis taklim is processed, it is resulted that the $\mathrm{R}$ Square (coefficient of determination) value is 0.684 . This result indicates that the commodification of religion in the majelis taklim of Bandar Lampung can be explained by the modernity 
variable of $68.4 \%$. This means that modernization and religious commodification are significantly correlated. The $\mathrm{R}$ Square 0.684 also means that modernity in the socio-demographic and structural aspects has a significant contribution to the commodification of religion.

The Annova test, or the F test, of this data reveals that the Anova (F) score is 720.743 , with the significant 0.000 . Because the probability level is 0.000 , or lower than 0.05 , therefore, in order to find out the effect of modernity on the majelis taklim congregation with regards to the practices of religious commodification among members of the majelis taklim, a regression model is needed.

The regression model test revealed the following regression equation: the constant score is 4.828 and the regression coefficient is 0.900 . This indicates that as much a change in socio-demographic behavior and organizational structure is found in the majelis taklim congregation in Bandar Lampung, the behavior of its members with regards to religious commodification will also increase.

The next data analysis involves a testing on the constant significance between the independent variable (modernization) and the dependent variable (commodification of religion). This test is done in order to find out whether modernity can be used to predict the religious commodification behavior. The constant significance test is scored 2.325 with the $t$ count 26.847. From these scores, it can be said that the modernist views of political contestants (parties) are influential to the making of religious values, dogmas, and religious symbols as political commodities, which in turn effect the views of the majelis taklim members in conveying their aspirations (political behavior).

Members of the majilis taklimin Bandar Lampung are closely linked to those politicians running for local and national elections. This is because majelis taklim has been used by the latter as a political space in which they get around the religious messages for their political campaigns. By this, religion is deprived of its sacred values and turned into a commodity, used as an exchange for political votes.

The practices of religious commodification by politicians can be discerned from the social behavior of the members of the majelis taklim congregation. The data shows that many of the members of the majelis taklim admitted that during following the learning activities in the majelis, they often encountered with politicians who visited their congregation offering religious products in favor of their running for political elections. 
Mostly, the politicians would offer Islamic clothing, or a travelling package to religious destinations, such as to Mecca for doing umrah, or bringing a reputable Muslim preachers upon their funding to give religious preaching in the congregation, in exchange of the politicans' electoral supports. To this offer, most of the members of the congregation are more than willing to accept. Another way, the politicians will join the congregation by becoming a guest speaker, delivering religious lectures that indirectly dictate political choices of the members of the majelis taklim. The commercialization of majelis taklim activities is a form of religious commodification perpetrated by politicians by concealing religious messages for electoral supports.

The practices of commodification also involve the members of the majelis taklim congregations, as they expected and accepted to receive the 'religious gift' offered by the politicians in exchange of their political ballots. The presence of politicians running for elections in the congregation was warmly welcomed by the member of the majelis taklim, as the latter was hoping that the former was coming with a bunch of transactional gifts at their hands.

Most respondents viewed the use of the hijab (covering the head) as a life style, apart from religious order. In addition, while most of them also viewed that pilgrimage to Mecca for umrah or hajj, is more important than other worship, they also considered that it is a social necessity. Therefore, most of them would make tremendous efforts to do the pilgrimage.

The practices of religious commodification among members of the majelis taklim congregation are influenced by the modernist standpoints formed by politicians visiting to the majelis taklim congregation, which in turn shape the political behavior of the majelis taklim members. At the conception level, modernization is related to a psychological process, that enables a person to change. The psychological process begins with urbanization. It starts from the decreasing level of illiteracy, followed by the increase in openness to mass media, economic participation, and finally to political participation.

Modernization has also urged people to lose their spiritual meaning when practicing their religions. Modern society begins to question the existence of religion and makes religion a perpetual feature of socio-cultural systems. The psychological shift of majelis taklim congregation regarding religion is due to the high intensity of political contestants in socializing transformation, especially related to the economic welfare of the members of the majelis taklim congregation. 
Technological advances have encouraged the process of modernization among members of the majelis taklim congregation. Modern technology has enabled the members of the majelis taklim to accept more easily the religious messages delivered by the politicians. Thanks to the use of smartphones, political view has become easier to convey and understand. Another modernization process that occurred in the majelis taklim congregation is related to the behavior of the majelis taklim members, who are always expected to act in accordance to the habits of the community, as well as to establish good social relations among themselves, on the basis of values that existed in the taklim majelis. All of these features have only made it easier for politicians to deliver their political messages.

The politicians seem to fully comprehend that the behavior of majelis taklim members is based on religious norms. It is the politician's knowledge about these religious norms that have in turn enables the politicians to mold the former into a commercial product. The fact that members of the majelis taklim have their own circles of sociability outside the majelis taklim congregations, and have the ability to influence those who are in the proximity of those circles, the practices of religious commodification has an extended influences beyond the congregations.

\section{Conclusion}

To conclude, there is a complex interwoven between modernization, politics, and religious commodification in shaping the behavior of the female members of the majelis taklim congregations in Bandar Lampung, especially in matters related to political issues. This may mean that features of modern society such as the urbanization of knowledge, increased income, technological advances, social norms, social interaction, and social institutions, all have been influential to the making of religious commodification and its practices among members of the majelis taklim congregation in Bandar Lampung. The practices of such religious commodification includes, for instance, the making of religious activities into a commodity, the commercialization of religious activities, and the forming of social relationships within the logic of economic relations. This paper concludes that in the ends, the practices of religious commodification in the field of politics have in turn shaped the political behavior of members of the majelis taklim. 
Modern Islam, Politics, and the Making of Religious Commodification...

\section{References}

Alles, Gregory D. Religious Studies: A Global View. New York: Routledge, 2008.

Bakri, Syamsul. "Modernisasi dan Perubahan Sosial Dalam Lintasan

Sejarah Islam.” KALIMAHVol. 14, no. 2 (2016).

https://doi.org/10.21111/klm.v14i2.611.

Batubara, Ariyandi, dan Abdul Malik. "Komodifikasi Agama dalam Ruang

Politik di Seberang Kota Jambi.” Kontekstualita: Jurnal Penelitian

Sosial Keagamaan Vol. 29, no. 2 (2014).

Fakhruroji, Moch. "Agama Dalam Pesan Pendek: Mediatisasi dan

Komodifikasi Agama Dalam SMS Tauhiid.” Universitas Gadjah

Mada, 2014.

http://publikasi.pasca.ugm.ac.id/catalog/?v=publikasi\&id=365.

Hadiyanto. Komunikasi Pembangunan Perspektif Modernisasi. Bandung:

IPB Press, 2014.

Hidayat. Pemikiran Islam Kontemporer. Bandung: Pustaka Setia, 2005.

Husna, Asmaul. "Komodifikasi Agama: Pergeseran Praktik Bisnis dan

Kemunculan Kelas Menengah Muslim.” Jurnal Komunikasi Global

Vol. 2, no. 2 (2018).

Kitiarsa, Pattana. Religious Commodifications in Asia. New York:

Routledge, 2008.

Martin, Richard C., dan Abbas Barzegar, ed. Islamism: Contested

Perspectives on Political Islam. California: Stanford University

Press, 2010.

Martono, Nanang. Sosiologi Perubahan Sosial. Jakarta: Raja Grafindo

Persada, 2014.

Maula, Bani Syarif. "Islam dan Modernitas: Pandangan Muslim Terhadap

Perkembangan Sosial.” Fikrah: Jurnal Ilmu Aqidah dan Studi

Keagamaan Vol. 5, no. 2 (2017).

Meuleman, Johan Hendrik, ed. Islam in the Era of Globalization. New

York: Routledge, 2002.

Mosco, Vincent. The Political Economy of Communication. London:

SAGE Publication Ltd, 2009.

Nata, Abuddin. Peta Keragaman Pemikiran Islam di Indonesia. Jakarta:

Raja Grafindo Persada, 2001. 
Okoli. "Materialism and Commodification of The Sacred: A Political Economy of Spiritual Materialism in Nigeria." European Scientific Journal Vol. 10, no. 14 (2014).

Osella, Filippo, dan Benjamin Soares, ed. Islam, Politics, Anthropology. United Kingdom: John Wiley \& Sons, Ltd, 2010.

"PORTAL Berita Resmi Pemerintahan Kota Bandar Lampung." Diakses 30 Agustus 2019.

https://bandarlampungkota.go.id/new/kecamatan.html.

Rozaki, Abdur. "Komodifikasi Islam: Kesalehan dan Pergulatan Identitas di Ruang Publik.” Jurnal Dakwah Vol. XIV, no. 2 (2013).

Setiawan, Muhammad Ferri. "Commodification of Religious Tradition." Yogyakarta, 2016.

Sinha, Vineeta. Religion and Commodification: Merchandizing Diasporic Hinduism. New York: Routledge, 2011.

Suprapto, dan Miftahul Huda. Antara Penguatan Identitas danKomodifikasi Agama. Mataram: Universitas Islam Negeri Mataram, 2018.

Zaenurrosyid, A., dan Lucy Zulies Ulfiana. "Komodifikasi Agama dalam Islamic Tourism dan Aktivitas Ekonomi.” Islamic Review: Jurnal Riset dan Kajian Keislaman Vol 5, no. 1 (2018). 